УДК 94.4

Михаил ВЕДЕРНИКОВ

\title{
СООТНОШЕНИЕ ВНЕШНИХ И ВНУТРЕННИХ ФАКТОРОВ В РЕАЛИЗАЦИИ ПОЛИТИЧЕСКИХ ПРОЕКТОВ ЧЕХОСЛОВАКИИ
}

Аннотация. ХХ век стал наиболее насыщенным и сложным для чехословацкого народа. В ходе столетия чехи и словаки сумели не только обрести государственность, но и потерять её. Впрочем, после утраты она была восстановлена. Синусоидное развитие страны, которая за это время испытала на себе разные модели политического развития - от национал-социализма и до коммунизма, традиционно объяснялось воздействием внешних сил, которые вовлекали государство в орбиту своего влияния. Однако в историографии вопроса калейдоскоп политических изменений редко поддавался анализу с позиции внутреннего генезиса политической жизни общества. В статье рассматриваются дополнительные факторы, оказывавшие влияние на устойчивость того или иного режима; обосновывается предрешенность некоторых форм организации политической жизни чехов и словаков; делается вывод о том, что проекты, насажденные в государство извне и не имевшие должной идеологической базы внутри, были обречены на постепенную деформацию и последующую замену. В свою очередь государственный строй, внедренный в Чехословакии после 1989 г., отличался от предшествующих тем, что он был исторически осмыслен и имел под собой прочную почву, что подтверждается устойчивым развитием страны по нынешний день.

Ключевые слова: Чехия, Чехословакия, Первая мировая война, Т.Г. Масарик, парламентская демократия, А. Дубчек, Пражская весна, социализм с человеческим лицом, «бархатная» революция, В. Гавел, перестройка.

\section{Введение}

Чехословакия (ЧСР) в рамках так называемого короткого XX в. ${ }^{1}$ прошла путь, который характеризуется неоднократной сменой политических режимов, отличающихся друг от друга противоположным идеологическим наполнением, противостоящими ценностными категориями. Так, в 1918 г. на смену абсолютистской вла-

\footnotetext{
${ }^{1}$ Известный историк Э. Хобсбаум ввел данное понятие, которое вбирает в себя период с 1914 по 1991 гг., когда произошли грандиозные события, оказавшие существенное влияние на облик современного мира. (См.: Хобсбаум Э. Эпоха крайностей: короткий двадцатый век (1914-1991). M., 2004.
}

() Ведерников Михаил - кандидат исторических наук, старший научный сотрудник Центра Вишеградских исследований Института Европы РАН. Адрес: 125009, Москва, ул. Моховая, 11-3.E-mail: vishma@mail.ru. 
сти Габсбургов приходит чехословацкая демократия, которая рассматривалась современниками в качестве преграды на пути к авторитарной концентрации власти в руках одной политический силы. Затем парламентаризм насильственным путем смещается диаметрально противоположным тоталитарным политическим режимом, основанным на постулатах германского национал-социализма и идеологии Третьего рейха, установление которого, несомненно, повернуло развитие Чехословакии вспять. Поражение гитлеризма и победа советских сил во Второй мировой войне привели к популяризации и проникновению в ЧСР коммунистических идей, которые на протяжении следующих 40 лет становятся лейтмотивом политической жизни страны. Таким образом, идеология государства стала строиться на принципах, которые подвергались критике как в демократической республике Т.Г. Масарика, так и в тоталитарном Протекторате Богемии и Моравии ${ }^{1}$. Заметным эпизодом в истории определения ценностной ориентации Чехословакии стала дискуссия о реформировании социалистического пути развития, о возврате к демократическому прошлому и о реставрации широких свобод, которая возникла в 1968 г. Однако на тот момент существующий политический строй показал свою жизнеспособность и просуществовал ещё 20 лет. Возрождение и претворение в жизнь идеологии Пражской весны состоялось в 1989 г. и сопровождалось массовым обвинением коммунистической партии (КПЧ) и её сторонников. В Чехословакии был сделан выбор в пользу отказа от социалистического прошлого и выбрано направление на развитие демократических институтов, вдохновение для которых бралось в межвоенной республике Масарика.

Таким образом, стоит говорить о трех попытках создания/восстановления независимого чехословацкого государства (в 1918, 1945, 1989 гг.), первые две из которых завершились крахом. В общем потоке восхваления достижений межвоенной республики исследователи не обращают внимания на неготовность населения воспринять идеологические концепции новообразовавшейся Чехословакии - их сложность и отход от прежних традиций․․ Эксперты преимущественно связывают изменения, произошедшие в 1938 г., с внешним фактором, с процессами, происходившими за пределами страны. Широко критикуемый коммунистический режим, установившийся в феврале 1948 г., также отождествляют с давлением внешних сил, несмотря на полярное отношение внутри чехословацкого общества к идеям комму-

\footnotetext{
${ }^{1}$ Протекторат нацистской Германии был создан в марте 1939 г. после оккупации Чехословакии. Он просуществовал вплоть до момента безоговорочной капитуляции Германии перед союзниками по антигитлеровской коалиции (8 мая 1945 г.).

${ }^{2}$ Так, Карел Крамарж, лидер Национальной партии свободомыслящих и первый премьерминистр Чехословакии, после войны продолжал отстаивать идею о том, что именно Россия должна стать основой и гарантом внешнеполитической безопасности Чехословакии. Его позиция по «русскому вопросу», не соответствовавшая официальной концепции, стала решающей причиной его смещения с поста премьера в 1919 г. (см. подробнее: Серапионова Е.П. Карел Крамарж и Россия. 1890 - 1937. М., 2006. С. 487).

Современная Европа, 2018, № 7
} 
низма. В случае с 1989 г. происходит смешение внутреннего и внешнего фактора, где главенство того или иного сложно определить.

В этой связи встают на первый взгляд очевидные вопросы, требующие широкой трактовки: что подталкивало государство к таким существенным изменениям? что определяло политико-ценностный выбор Чехословакии? Был ли он предопределен исключительно внешними обстоятельствами, или его подоплека крылась в особенностях внутриполитического развития страны, или стоит говорить о взаимообусловленности факторов?

\section{Первая Чехословацкая республика: истоки возникновения и очевидный кри- зис функционирования}

К началу Первой мировой войны в Чешских землях существовало открытое недовольство политическим устройством Австро-Венгрии. Осознавая свой вес в рамках империи, чехи требовали от центральной власти бо́льших свобод. Накануне мирового столкновения шли переговоры о чешско-немецком соглашении, которое должно было предоставить чехам значительное расширение полномочий в рамках двуединой монархии. Однако запросы чехов касались лишь трансформации политико-государственного устройства империи, предоставления им определенных прав и не затрагивали устоев существования государства. Между тем первые дни войны привели к заметной радикализации чешской политической элиты, в рядах которой появились лица, заявившие о необходимости уничтожения Австро-Венгрии и создании независимой Чехии (затем Чехословакии). Важно отметить, что такие призывы отчетливо прозвучали в странах, где проживали крупные чешско-словацкие диаспоры (Россия, Франция, США). Подобные устремления были поддержаны сначала русскими и французскими властями, а затем и американскими. Чешские политические элиты, оставшиеся в империи, стояли «на безоговорочно лоялистских позициях» и до середины 1918 г., когда исход войны уже стал понятен, «не выдвигали требований радикальнее, чем автономия в составе Габсбургской монархии» [Бобраков-Тимошкин А., 2008: 16]. Главные, как потом оказалось, оппоненты империи покинули ее пределы и сражались с ней на дипломатических полях иностранных представительств стран Антанты. Среди них был и Т.Г. Масарик, чешский общественно-политический деятель и лидер непопулярной партии реалистов - впоследствии первый президент Чехословакии.

Однако необходимо подчеркнуть тот факт, что вплоть до осени 1915 г. его деятельность была малозаметна и не вызывала должного интереса у официальных лиц Франции и Великобритании, куда он направился в конце 1914 г. из АвстроВенгрии. В свою очередь его соотечественники, проживавшие на момент объявления войны в Российской империи и заявившие о необходимости создания самостоятельного чешско-словацкого государства, были более успешны, поскольку их проекты получали одобрение, особенно в начале войны, со стороны российских официальных властей. В подобной обстановке Масарику приходилось лавировать и 
подстраивать свои политические заявления к внешнеполитической обстановке тех дней. Осознавая ключевое значение России в определении будущего Чехии и Словакии, он подчеркивал необходимость идти рука об руку с ней и уточнял, что «её желания по поводу ключевых вопросов будут определяющими» [Ведерников М., 2015: 124]. Между тем он не прекращал продвигать чешско-словацкие интересы как в Париже, так и в Лондоне - желая таким образом «усидеть на двух стульях». Расчет Масарика увенчался успехом, когда в феврале 1917 г. в России была свергнута монархия и страна начала постепенно погружаться в анархию гражданского беспорядка, вызванного начинающейся междоусобной войной. В ситуации, когда сила, которая ранее рассматривалась Масариком в качестве проводника идеи чешско-словацкой независимости, была нейтрализована, его внимание переключилось на оставшихся союзников по Антанте.

Таким образом, события Первой мировой войны показали чрезвычайную важность внешнеполитического фактора в деле государственного строительства, поскольку зарождающееся государство в 1918 г. формировалось руками победителей (Франция, Великобритания, США), определявших его границы, национальный состав, форму правления и т.п. В этой связи можно говорить о Чехословакии как о «продукте Версальской системы». Впрочем, шаткость этой системы, о чем начали говорить ещё во время подписания мирных договоров с проигравшими странами르, не могла не сказаться и на прочности самой Чехословакии. В сознании современников гарантом соблюдения международных договоренностей должна была выступить Франция, которая в период с 1918 по 1938 гг. не без основания становится идейно-политическим ориентиром Чехословакии, отчасти из-за желания Масарика более интенсивно участвовать в решении европейских проблем. В этой связи некоторые исследователи отмечают, что в это время был сделан существенный поворот в направлении внешнеполитического курса, поскольку ранее чешские политики большее внимание уделяли разработке вопросов, касающихся отношений с ближайшими соседями и с Россией. Отказ от политической традиции, в которой доминировала ориентация на «большого восточного соседа», её смещение в сторону западных союзников привели к нарушению устоявшегося уклада партийнополитической жизни чехов и словаков. Так, накануне войны наиболее авторитет-

\footnotetext{
${ }^{1}$ Версальско-Вашингтонская система международных отношений - мировая система политического устройства, которая была установлена по итогам Первой мировой войны. Она опиралась на положения Версальского мирного договора, на договоры с союзниками Германии (Сен-Жерменский, Нёйиский, Трианонский, Севрский) и соглашения, заключенные в ходе Вашингтонской конференции 1921 - 1922 гг.

2 Французский маршал Ф. Фош, узнав о подписании Версальского мира в 1919 г., воскликнул: «Это не мир, это перемирие на 20 лет...» (см.: Айрапетов О.Р. Участие Российской империи в Первой мировой войне (1914 - 1917): 1914. Начало. М., 2014. С. 21).

Современная Европа, 2018, № 7
} 
ными партиями были те, которые постулировали необходимость тесного взаимодействия с Российской империей ${ }^{1}$.

Помимо этого, определенные круги населения и элита отнеслись настороженно к идейной ориентации государства, заданной сильной личностью президента Масарика [Бобраков-Тимошкин А.Е., 2008: 20]. Будучи выдающимся мыслителем своего времени, он сумел создать определенный идеологический фундамент Чехословакии, который базировался на его личном понимании смысла чешской истории и месте произошедших в годы войны событий. Он хотел показать вовлеченность чехословацкого народа в мировое развитие, определяя его как часть большого целого, где существовало равноправие между его членами. Подобные идеологемы были трудны для восприятия обывателю. В этой связи стоит согласиться с русским филологом-славистом С.Г. Вилинским, вынужденным эмигрировать после русской революции в Чехословакию: «Т.Г. Масарик - это светило этики, пророк гуманности и глашатай высших истин... остался непонятым своим народом как должно» [Фирсов Е.Ф., 2012: 262].

Можно говорить об определенной противоречивости появившегося в 1918 г. чехословацкого государства. Прежде всего это выразилось в отсутствии понимания среди широких масс идейного базиса государства, его идеологического наполнения. Подобное стало возможным во многом из-за того, что изменения, постигшие Чешские земли и Словакию по итогам мировой войны, не были результатом длительного внутриполитического развития, а стали ответом на вызов времени и были насаждены практически извне. В этой связи для удержания политического режима «на плаву» требовался особый политический инструментарий, сплачивающий общую концепцию чехословацкого государства. А.Е. Бобраков-Тимошкин говорит о формировании нескольких мифов, которые устойчиво поддерживались в межвоенное время [Бобраков-Тимошкин А.Е., 2008: 68-72]. Для нас наиболее важен миф о Масарике как символе, объединившем людей внутри страны; миф об освобождении как «торжестве “своих" в рамках бинарной модели “свой-чужой”»; миф о «любимцах Антанты» - позиции официальной пропаганды, согласно которой Чехословакия имела крепкое международно-политическое положение благодаря благоволению стран Согласия.

Зная последующий ход событий, который привел к разрушению парламентской демократии Масарика, встает вопрос был ли подобный исход предопределен исключительно внешними факторами, т.е. агрессией со стороны Германии, или существовали определенные предпосылки, свидетельствующие о смещении вектора политического развития в сторону его деградации?

На фоне мюнхенской трагедии проблемы внутреннего развития страны и вопросы путей развития парламентской системы зачастую остаются в тени. Между тем можно говорить о перманентном кризисе её функционирования, свидетельст-

\footnotetext{
${ }^{1}$ Прежде всего следует назвать Национальную партию свободомыслящих, лидер которой К. Крамарж был известным русофилом и автором проекта славянской федерации, и Чешскую национально-социальную партию.
}

Современная Европа, 2018, № 7 
вом чего являются 18 правительственных кабинетов, сменившихся за 20 лет существования республики. Э. Бенеш, верный соратник Т.Г. Масарика и второй президент ЧСР, размышляя о причинах гибели страны в 1938 г., обращал внимание на многочисленность политических партий. По его мнению, это вело к подмене государственных интересов партийными, к атомизации государства, к олигархическому партийному управлению и к неспособности быстро реагировать на возникавшие трудности [Чехия и Словакия..., 2005: 117]. Во время кризисов возникали различные формы неконституционного политического правления, например, так называемая Пятёрка в начале 1920 -х гг.

Происходило последовательное ограничение парламентской демократии, связанное с установлением системы широких полномочий, в результате которой права высших законодательных органов парламентской власти отчасти делегировались исполнительной власти [Фирсов Е.Ф., 1997: 5-6]. Так, в результате принятия Особого закона (9 июня 1933 г.) правительству предоставлялась возможность с согласия президента и в обход парламента принимать важные решения [Фирсов Е.Ф., 1997: 193]. Подобная модификация парламентской системы, по мнению чешского историка В. Менцла, была «противоречивым процессом, который был направлен не на совершенствование, а на разрушение и формализацию изначальных конституционно-демократических принципов и на постепенную интеграцию трех основных сфер власти в новую систему, которая характеризовалась еще большей фактической, а в итоге формальной монополизацией государственного и политического руководства» [Mencl V. a kol., 1990: 149]. Как отмечает Е.Ф. Фирсов, данные изменения привели к формированию монополистического блока из влиятельных кругов экспортного и промышленного капитала, заинтересованного в усилении государственных рычагов регулирования экономики. Такая трансформация во многом была предопределена обновленной расстановкой сил в Европе после прихода к власти национал-социалистов в Германии и их реваншистскими заявлениями относительно итогов Первой мировой войны. Тенденции к преобразованию политического строя отчетливо проявились накануне «Мюнхена», когда президент республики Э. Бенеш передал задание В. Боучеку, одному из создателей чехословацкой конституции, в котором просил его «проштудировать смысл и букву основного закона страны с точки зрения возможной легализации прямой диктатуры», которая бы полностью опиралась на волю армии, желавшей защищать свое народное достояние и государство ${ }^{1}$. Несомненно, что такой проект мог появиться только в исключительных обстоятельствах предотвращения капитуляции страны перед Германией. Между тем существование подобного инструмента в арсенале политиков говорит о

\footnotetext{
${ }^{1}$ Письмо полпреда СССР в Чехословакии С.С. Александровского наркому иностранных дел СССР М.М. Литвинову о настроениях в правящих кругах и в армии Чехословакии в связи с политическим давлением Великобритании в судето-немецком вопросе... // Архив внешней политики Российской Федерации. Ф. 05. П. 149. Д. 167. Л. 174 - 178. URL: http://munich.rusarchives.ru/dokumenty/pismo-polpreda-sssr-v-chehoslovakii-ssaleksandrovskogo-narkomu-inostrannyh-del-sssr-mm-litvinovu-o
} 
том, что чехословацкая демократия имела явную тенденцию к деформации в сторону ограничения демократических свобод и ценностей.

Анализируя вышесказанное, можно отметить, что на момент создания самостоятельного чехословацкого государства проецируемая на него политическая модель не соответствовала реальному уровню развития политических субъектов государства. Так, идеологические построения Т.Г. Масарика, который вкладывал в проект формируемой Чехословакии дополнительное философское содержание, выведенное из его многолетнего творческого поиска, наталкивались на простое непонимание со стороны не только граждан, но и политиков. Можно говорить о том, что происходила «подгонка реальности под идеологическую программу» [БобраковТимошкин А.Е., 2008: 150]. Будучи продуктом Версальского мира, Чехословакия закономерно вынуждена была столкнуться с последствиями, связанными с неустойчивостью системы, её половинчатостью и заложенной в ней способностью к саморазрушению.

\section{Пражская весна: неудачная попытка совмещения социализма с капитализ- Mo $\boldsymbol{M}$}

После Второй мировой войны, в результате которой был положен конец хищническим притязаниям гитлеризма на глобальное господство в мире, коммунистическая идеология начала распространяться в государствах Центральной Европы. В 1948 г., после прихода к власти в Чехословакии Коммунистической партии (КПЧ), страна была включена в зону советского влияния, что предопределило её участие в военно-политических и экономических блоках, созданных под эгидой СССР (Совет экономической взаимопомощи, Организация Варшавского договора - СЭВ и ОВД), и отказ от участия в плане Маршалла. Однако вслед за горячей фазой мировой войны последовала холодная, в которой столкнулись два противостоящих союза: один - во главе с США, другой - во главе с СССР. Выбор Чехословакии в пользу построения коммунизма объяснялся колоссальными достижениями Советского Союза в ходе борьбы с Третьим рейхом, в то время как успехи союзников по антигитлеровской коалиции не были столь впечатляющими, и они не могли конкурировать с ним на достойном уровне. Более того, КПЧ ещё в довоенное время сумела заручиться поддержкой населения, что упрощало распространение её идей ${ }^{1}$. Таким образом, можно констатировать, что политико-ценностный выбор Чехословакии в

\footnotetext{
${ }^{1}$ Как сообщал в 1925 г. член политбюро КПЧ Гакен, «нигде в капиталистической Европе не существует такой сильной, массовой и влиятельной партии, как КПЧ». В межвоенном парламенте она имела около $10 \%$ голосов. (цит. по: Чехия и Словакия в XX веке: очерки истории. М., 2005. Кн. 1. С. 144).

Накануне февральских событий 1948 г., по сведениям историка К. Каплана, в КПЧ входили 1250 тыс. человек. (см.: Волокитина Т. В., Мурашко Г. П., Носкова А. Ф., Покивайлова Т. А. Москва и Восточная Европа. Становление политических режимов советского типа: $1949-$ 1953: Очерки истории. М., 2002. С. 155).
}

Современная Европа, 2018, № 7 
1948 г., также как и в 1918 г., был предопределен внешними факторами. Однако спустя 30 лет произошел сдвиг в сторону более обоснованного и осознанного выбора в пользу социалистической модели развития общества, поскольку существовала серьезная поддержка внутри чехословацкого общества ${ }^{1}$.

Впрочем, внедренная на европейскую почву сталинская модель строительства социализма, по мнению историка М.В. Латыша, могла дать толчок только развитию отсталых стран, помогая форсировать индустриализацию, насаждать тяжелую промышленность, урбанизировать население, повысить его образовательный уровень и др. Однако в случае с ЧСР, которая на тот момент находилась на высоком уровне экономического и культурного развития, она обернулась возникновением диспропорций не только в хозяйственной жизни, но и в сфере политики, а именно всевластием партийного аппарата и подавлением демократических свобод [Латыш М.В., 1998: 8]. Ч. Цисарж, один из видных деятелей Пражской весны, отмечал, что «внедрение модели “социализма по Сталину” стало катастрофической ошибкой кремлевских правителей». Он указывал на то, что оказались утрачены результаты гигантских усилий и решающего вклада Советского Союза в разгром нацистского вермахта... обеспечивших ему авторитет в глазах огромной части человечества» [Цисарж Ч., 2010: 18].

Уже в конце 1967 - начале 1968 гг. оперативные службы СССР не только констатировали факты общественного недовольства в Чехословакии, но и называли диагноз нараставшего кризиса, свидетельствуя об угрозе целостности социалистического блока и вызовах советской догматической системе [Павленко О.В., 2010: 53]. Возникновение подобных настроений было вызвано комплексом мер, направленных на демократизацию режима, появление свободы печати, проведение экономических преобразований (так называемая Пражская весна). Между тем сами инициаторы чехословацких реформ во главе с А. Дубчеком не выступали за разрыв с существующей системой. Они говорили об «улучшении социализма», его обновлении, построении «социализма с человеческим лицом» [Чехия и Словакия в XX веке, 2005: 163]. Движение, зародившись внутри компартии среди номенклатурной элиты, изначально было нацелено на «спасение на долговременную перспективу марксистских добродетелей», на его избавление от поздних наслоений. Но по мере того как движение распространялось среди широких масс, их порыв начал получать либерально-демократическое звучание и поступательно продвигался в направлении демократической перестройки авторитарного режима в гражданское общество [Цисарж Ч., 2010: 21].

\footnotetext{
${ }^{1}$ Один из идеологов Пражской весны, чехословацкий политик, секретарь ЦК КПЧ 3. Млынарж, писал: «В Чехословакии 1945 года поклонение Советскому Союзу и Сталину не противоречило общенародному стремлению к свободе и справедливости, которые должны были воцариться в новом государстве. Напротив, поклонение было органической составляющей этого стремления, наполняло его конкретным содержанием борьбы за социальную справедливость и равенство людей. ... Советский Союз был страной сбывшихся надежд». (Млынарж 3. Мороз ударил из Кремля. М., 1992. С.4).

Современная Европа, 2018, № 7
} 
Говоря о факторах, которые сделали возможным осуществление, хотя и не успешной попытки, преобразований, необходимо обратить внимание на то обстоятельство, что во главе этого процесса в основном стояли люди, которые воспринимали свою страну как самостоятельное государство с самого рождения. В отличие от граждан межвоенной Чехословакии, для которых сначала появление государства, а затем его существование было новым явлением, их соотечественники в 1960-х гг. четко осознавали самоценность независимого государства. Многие из них были свидетелями «Мюнхена». В этой связи гуманистическая идеология Т.Г. Масарика, к которой обращались многие сторонники Пражской весны, приобретала актуальность и ценность. Она уже была осознана самостоятельно и не насаждалась сверху, как это подчас делалось в период с 1918 по 1938 гг. Однако трансформация социализма по мере нарастания размаха реформ стала выходить за рамки допустимо возможного сценария, который члены ОВД могли себе позволить.

Несомненно, руководители государств членов ОВД осознавали опасность ситуации для всего социалистического блока. Генеральный секретарь ЦК КПСС Л.И. Брежнев говорил о непозволительности «поворота Чехословакии на капиталистический путь, ослабления мощи Варшавского договора, разрушения единства социалистической системы, всего коммунистического и национально-освободительного движения» [Пражская весна... 2010: 137]. Превалировало суждение о невозможности рассмотрения реформаторского движения в Чехословакии изолированно от вопроса об общем идеологическом сопротивлении между империализмом и коммунизмом. Константой выступлений был мотив о масштабной идеологической борьбе, начатой врагом и нацеленной на разрушение социалистического лагеря. Было распространено мнение, что за внешне разрозненными вылазками антисоциалистических элементов стоит организационный центр, который дирижирует этими выступлениями из Бонна (ФРГ) и Вашингтона (США). Особая роль в дискредитации «мировой социалистической практики» отводилась 3. Бжезинскому, советнику президента Соединенных Штатов Л. Джонсона в Праге, который после прибытия в Чехословакию и серии публично прочитанных лекций о преимуществах «американского империализма» якобы способствовал публикации одного из основных про-

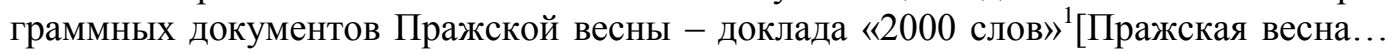
2010: 128-130].

Будучи расположенной в самом центре Европы, на разделительной линии двух противостоящих идеологических лагерей, Чехословакия не могла не стать эпицентром их столкновения. Несмотря на отсутствие горячей фазы борьбы, соперничество было очевидным. В этой схватке социализм показал свою мощь, поскольку, во-

\footnotetext{
${ }^{1}$ Во время своих выступлений он открыто заявлял, что события в Чехословакии являются частью концепции США - переброски мостов в Восточную Европу. Что касалось западной политики в отношении этого региона, то она заключалась в мирной привязке, в координированном использовании культурных связей, в дипломатическом маневрировании и содействии «разлагающимся силам». Советник Л. Джонсона Гофман эту стратегию назвал «соблазнением Европы».
} 
первых, политическая система находилась на одной из пиковых точек своего развития, а во-вторых, в 1968 г. Запад явно не был готов спасать демократию, поскольку любая силовая операция ввиду широкого протестного движения во Франции, США, Великобритании, ФРГ была чревата новыми демонстрациями и выступлениями. Таким образом, Чехословакия под воздействием внешних обстоятельств была вынуждена на следующие 20 лет остаться в лагере победителя, как это произошло после окончания двух мировых войн. Определенно подавление Пражской весны, не вызвавшее особых сложностей у воинских частей ОВД, нанесло непоправимый и сокрушительный удар имиджу СССР (и России, в частности), а в более широком понимании - всей социалистической системе. Грубое использование армии надломило веру в Советский Союз, и удержание этого строя в следующие 20 лет зависело исключительно от его геополитического положения в мире.

Рассуждая о соотношении внутренних и внешних факторов в выборе политической ориентации Чехословакии в 1945-1968 гг., необходимо отметить возросшее значение чехословацкого общественно-политического движения, представители которого поначалу приветствовали установление коммунистического режима, затем, разочаровавшись в нем, заявили о необходимости его реформирования. Столкновение в ходе Пражской весны подобной инициативы (внутренний фактор) с жестким диктатом со стороны союзников (внешний фактор) завершилось в пользу последнего. Однако при всей его доминантности внутренние силы, разочаровавшиеся в социализме, на протяжении последующих лет расширяли свое влияние, вовлекая в свои ряды новых сторонников. Требовались подходящие внешние обстоятельства для реванша.

\section{«Бархатная» революция}

Последовавший за подавлением Пражской весны 1968 г. период истории Чехословакии получил определение «нормализация». Её смысл сводился к приведению национальной политической системы в исходное, соответствующее определенному стандарту положение. В качестве модели был выбран вариант внедрения наиболее жестких мер, направленных на полную ликвидацию достижений реформистского движения в политической и экономической сфере. В результате многие требующие решения вопросы остались без ответа. Ввиду этого завершились попытки привнесения элементов рыночной экономики в хозяйственную систему; посредством закрытия многих СМИ были ликвидированы плюрализм мнений и свобода слова; приостановлена демократизация партии и общественной жизни; остался неразрешенным вопрос об урегулировании отношений чехов и словаков на федеративном уровне.

Между тем идейная борьба после крушения Пражской весны не была полностью подавлена и открыто продолжалась как чехословацкими общественными деятелями в самой стране (писателями, философами, учеными), возможности у которых с каждым годом, вплоть до 1980-х гг., уменьшались, так и теми представите- 
лями интеллигенции, которые были вынуждены эмигрировать за рубеж. Впрочем, предыдущий опыт идейного поиска пути развития отчетливо показал, что «почва» для его культивирования была более приспособлена именно внутри самой страны. Идеи, привнесенные извне, начиная с Т.Г. Масарика и заканчивая коммунистами, несмотря на их повсеместное внедрение, спустя время демонстрировали свою непригодность и замещались более актуальными. В этой связи период с 1968 по 1989 г. отмечен именно внутренним поиском чехословацкого варианта обустройства государства. Так, невозможность проведения альтернативной политики в рамках привычных институтов из-за тотального насаждения коммунистической парадигмы вела к тому, что ею стала заниматься интеллигенция, в особенности представители гуманитарных направлений знания. В главном программном документе чехословацкого диссидентского движения - Хартия-77 - говорилось о том, что «честным людям необходимо выступать против диктатуры только без вовлеченности в политику, особенно в её рутинные процедуры». При этом следовало опираться на «особое политическое значение нравственного аспекта». Помимо прочего, выдвигалась концепция «неполитической политики», которая сводилась к призыву жить по правде и, по крайней мере, не поддерживать наполненных пустотой государственных ритуалов, ставших опорой «режима нормализации» [Задорожнюк Э., 2012: 17].

После прихода к власти в СССР М.С. Горбачева и начала в 1985 г. в стране перестройки, приведшей к «радикальной переделке общественного здания Советского государства - от экономического фундамента до политической надстройки» [Beдерников М.В., 2018: 9], - в Чехословакии начали появляться реальные возможности для трансформации строя. Диссиденты, которые ранее подвергались преследованиям, стали полноценными участниками политической жизни, их оппозиция КПЧ, попадая на плодородную почву неприятия этой партии, получала широкую поддержку у населения, желание изменений у которого год от года только возрастало. Результатом стало осуществление «бархатной» революции в 1989 г., в ходе которой без насилия и крови удалось ликвидировать господство коммунистической идеологии, предоставив возможность для развития демократии, свободы слова, политического плюрализма. Однако и в этот раз важно обратить внимание на то, что «ветер перемен», приведший к ценностному повороту Чехословакии, исходил не из самого государства, а был вызван внешними факторами, возникновение которых не было инициировано внутренним развитием Чехословакии. И всё же стоит отметить, что в данном случае сдвиг политических пластов соответствовал интересам противников КПЧ и сочетался с их программными установками, которые впоследствии они сумели развить в более радикальном направлении, а именно в «остракизации» КПЧ, повороте в сторону сближения с западными военно-политическими блоками и т.п. Таким образом, необходимо констатировать, что впервые в истории Чехословакии внешний фактор способствовал укоренению общего тренда развития общества и не насаждался извне.

Следует выделить особую значимость «доморощенности» нового политического режима. В предшествующие годы политические конструкты, внедряемые в Че-

Современная Европа, 2018, № 7 
хословакии, навязывались населению, которое было практически вынесено за рамки процесса принятия решения об их имплементации. Одобрение того или иного строя было разное в зависимости от тех преимуществ, которое оно поначалу предоставляло, - от отрицания фашистской диктатуры до эйфорийного одобрения независимого государства Т.Г. Масарика. Между тем в каждом из случаев население ставилось перед фактом необходимости дальнейшей жизни в рамках данной политической системы. В случае с тем вариантом устройства государства, который был принят за основу нового государства в 1989 г. - курс «на возвращение в Европу, широкие массы были активными участниками этого процесса. Можно говорить о том, что подавление Пражской весны и последующее размещение войск ОВД на территории страны во многом способствовали началу процесса осмысления принадлежности чехов и словаков к «чехословацкому» государству.

\section{Заключение}

На протяжении 100 лет Чехословакия (с 1993 г. - Чехия) испытала на себе разные политические модели, которые находились на противоположных полюсах политико-ценностного ряда, начиная от ультраправой квазифашистской идеологии Протектората Богемии и Моравии и заканчивая левым коммунистическим строем сталинской модели. Между ними стоит поместить парламентскую демократию межвоенного и постсоциалистического времени. Можно предположить, что страна стала в это столетие неким подобием лакмусовой бумажки, на которой проявились многие недостатки - видимые и скрытые и преимущества - очевидные и малозаметные, возникавшие вне её пределов идеологий, и на которой происходила реакция на внутренние и внешние факторы, определявшие степень благоприятности того или иного строя не только для самой страны, но и для всей Европы. Несомненно, 1968 и 1989 годы показали обреченность социализма и коммунизма в Центральной Европе, их неприятие и бо́льшую склонность чехословаков к ориентации на Запад. Между тем эти события, помимо позитивного осознания необходимости отказа от них, привели, например, к обострению отношений между чехами и словаками и к последующему разделу единого государства.

Чрезвычайно важным для Чехословакии в течение всего обозначенного времени был внешнеполитический фактор, который выражался не только во влиянии событий за рубежом на положение самой страны, но и в неспособности внутренних политических сил зачастую формулировать повестку политического развития страны, что приводило к необходимости подчиняться идеям, развившимся за пределами Чехословакии (даже если их идейными вдохновителями были чехи или словаки). Это привело к утверждению масариковского проекта Чехословакии, политического колосса на глиняных ногах, и к приходу к власти коммунистов.

Политическая форма правления, которая установилась в Чехословакии (с 1 января 1993 г. - в Чехии и Словакии), после 1989 г. стала наиболее жизнеспособным вариантом, сумевшим просуществовать около 30 лет без явных потрясений, - pe- 
кордный показатель на сегодняшний день. Причина этого кроется в том, что подобная модель, во-первых, была осмыслена, разработана и опробована теми людьми, которые проживали внутри страны, видели объективные потребности общества и ощущали себя полноценными гражданами Чехословакии. То есть отсутствовал фактор насаждения извне. Во-вторых, страна вернулась к истокам межвоенной демократии, но в обстановке, когда широкие слои граждан смогли осознать самоценность этой системы - её исключительность. Именно проникновение гражданского сознания и демократизация масс стали залогом укоренения представления о Чехословакии как парламентской республике западноевропейского типа.

\section{Список литературы}

Бобраков-Тимошкин А., (2008) Проект ««Чехословакия»: конфликт идеологий в Первой Чехословацкой республике (1918-1938). М.

Ведерников М., (2015) Место России во внешнеполитической концепции Т.Г. Масарика накануне и в годы Первой мировой войны. Современная Европа. № 6. С. 122-130.

Ведерников М.В., (2018) Трансформация советско-чехословацких отношений после «бархатной революции» (1989-1991). Вестник Нижегородского университета им. Н.И. Лобачевского. № 3. С. 917.

Задорожнюк Э., (2012) Вацлав Гавел: портрет в интерьере исторической эпохи» // Славяноведение. № 5. C. 13-29.

Латыш М.В., (1998) «Пражская весна» 1968 г. и реакция Кремля. М.

Павленко О.В., (2010) Советские информационно-аналитические и оперативные материалы по чехословацкому кризису 1968 года. «Пражская весна» и международный кризис 1968 года. Статьи, исследования, воспоминания. М.

Пражская весна и международный кризис 1968 г., (2010) Документы. М.

Серапионова Е.П. (2006) Карел Крамарж и Россия. 1890-1937. Москва.

Фирсов Е.Ф., (1997) Опыт демократии в ЧСР при Масарике: коалиционный плюрализм (19281934). M.

Фирсов Е.Ф., (2012) Т.Г. Масарик в России и борьба за независимость чехов и словаков. М.

Цисарж Ч., (2010) Размышления о «Пражской весне» сорок лет спустя. 1968 год. «Пражская весна». Историческая ретроспектива: сборник статей. М.

Чехия и Словакия в XX веке: очерки истории, (2005) М.: Наука. Кн. 1, 2.

\section{References}

1968 god. «Prazhskaya vesna». Istoricheskaya retrospektiva: sbornik statej [Prague spring and the international crisis of 1968. Articles, research, memories]. Moscow.

Bobrakov-Timoshkin A., (2008) Proekt ««Chekhoslovakiya»: konflikt ideologij v Pervoj Chekhoslovackoj respublike (1918-1938 [Project "Czechoslovakia": conflict of ideologies in the first Czechoslovak Republic]). Moscow.

Latysh M.V., (1998) «Prazhskaya vesna» 1968 g. i reakciya Kremlya ["Prague spring" of 1968 and the Kremlin's reaction]. Moscow

Mencl V. a kol., (1990) Křižovatky 20. Stoleti [Crossroads of XXth century]. Praha.

Pavlenko O.V., (2010) Sovetskie informacionno-analiticheskie i operativnye materialy po chekhoslovackomu krizisu 1968 goda. «Prazhskaya vesna» i mezhdunarodnyj krizis 1968 goda. Stat'i, issledovaniya, vospominaniya. M.

Современная Европа, 2018, № 7 
Rychlík J., (1998) Český fašismus v meziválečném období a po roce 1939. Českoslovenství, středoevropanství, evropanství (1918-1938). Úvahy, svědectví a fakta. Brno.

Vedernikov M., (2015) Mesto Rossii vo vneshnepoliticheskoj koncepcii T.G. Masarika nakanune i v gody Pervoj mirovoj vojny [Russia's place in the foreign policy concept of T.G. Masaryk before and during the First world war]. Sovremennaya Evropa [Contemporary Europe], 6, 122-130.

Vedernikov M.V., (2018) Transformaciya sovetsko-chekhoslovackih otnoshenij posle «barhatnoj revolyucii» (1989-1991) [Transformation of Soviet-Czechoslovak relations after the "Velvet revolution" (19891991)]. Vestnik Nizhegorodskogo universiteta im. N.I. Lobachevskogo, 3, 9-17.

\section{Correlation of External and Internal Factors in the Implementation of Political Projects in Czechoslovakia}

Author. Vedernikov M. Candidate of Sciences (History), Research fellow of Department of Central and Eastern European studies, Institute of Europe RAS. Address: 11-3, Mokhovaya str., Moscow, Russia, 125009. E-mail: vishma@mail.ru.

Abstract. The XX century was the most difficult for the Czechoslovak people. During the century Czechs and Slovaks managed not only to gain statehood, but also lose it. However, after the loss it was restored. The sinusoidal development of the country, which during this time has experienced different models of political development - from national socialism to communism, has traditionally been explained by the influence of external forces. However, in the historiography of the issue, the kaleidoscope of political changes has not been analyzed from the standpoint of the internal genesis of the political life. In this regard, the article attempts to consider additional factors that influenced the stability of a regime, substantiates the predetermination of some forms of political organization.

Key words. Czech republic, Czechoslovakia, World War I, T.G. Masaryk, parliamentary democracy, A. Dubček, Prague Spring, socialism with a human face, velvet revolution, V. Havel, perestroika.

DOI: http://dx.doi.org/10.15211/soveurope720184761 